\title{
Clinical significance of exosomal miRNAs and proteins in three human cancers with high mortality in China (Review)
}

\author{
LI-MAN LI ${ }^{1 *}$, HUAN LIU ${ }^{2 *}$, XING-HUI LIU ${ }^{3}$, HONG-BIN HU ${ }^{4}$ and SONG-MEI LIU ${ }^{1}$ \\ ${ }^{1}$ Center for Gene Diagnosis, Zhongnan Hospital of Wuhan University; ${ }^{2}$ Department of Pathology, \\ Zhongnan Hospital of Wuhan University, Wuhan, Hubei 430071; ${ }^{3}$ Department of Clinical Laboratory, \\ Shanghai Gongli Hospital, The Second Military Medical University, Shanghai 200135; \\ ${ }^{4}$ Department of Blood Transfusion, Wuhan Children's Hospital (Wuhan Maternal and Child Healthcare Hospital), \\ Tongji Medical College, Huazhong University of Science and Technology, Wuhan, Hubei 430016, P.R. China
}

Received January 18, 2018; Accepted August 30, 2018

DOI: $10.3892 /$ ol.2018.9631

\begin{abstract}
Cancer is the second leading cause of mortality worldwide. More importantly, the mortality rates for cancer are increasing. In China, lung cancer, liver cancer and gastric cancer are the top three leading causes of mortality in males, whereas lung cancer, gastric cancer and liver cancer are ranked the top three causes of mortality in females. Exosomes are extracellular vesicles that are produced and released by many different cells; these vesicles have a size range between 30 and $100 \mathrm{~nm}$ in diameter, and contain a lipid bilayer. Exosomes exist in various bodily fluids, contain plentiful amounts of nucleic acids and proteins, and shuttle these materials between cells to mediate the development of cancers. The present review summarizes the composition of exosomes and methods for their isolation and then intensively highlights the latest findings on the contributions of exosomal microRNAs (miRNAs) and proteins to lung cancer, liver cancer and gastric cancer. Taken together, exosomal miRNAs and proteins may be used as noninvasive, novel biomarkers for cancer diagnosis, prognosis or precision treatment owing to their ability to promote tumor progression and metastasis, and their ability to regulate the immune response and tumor cell sensitivity to chemotherapy drugs.
\end{abstract}

\section{Contents}

1. Introduction

2. Exosome composition

Correspondence to: Professor Song-Mei Liu, Center for Gene Diagnosis, Zhongnan Hospital of Wuhan University, 169 Donghu Road, Wuhan, Hubei 430071, P.R. China

E-mail:smliu@whu.edu.cn

${ }^{*}$ Contributed equally

Key words: exosomes, exosomal miRNAs, exosomal proteins, high mortality cancers
3. Exosome isolation

4. Exosomal miRNAs and proteins in lung cancer

5. Exosomal miRNAs and proteins in liver cancer

6. Exosomal miRNAs and proteins in gastric cancer

7. Conclusion and future studies

\section{Introduction}

Cancer is the second leading cause of death globally (1). In China, the numbers of newly diagnosed cases and deaths were approximately 3.0 million and 1.9 million, respectively, in 2010 (2). According to 2013 data, lung cancer, liver cancer and gastric cancer are the top three leading causes of mortality in males in China, whereas lung cancer, gastric cancer and liver cancer are the top three leading causes of mortality in females (3) (Fig. 1).

A growing number of studies have focused on the biology, function and clinical implications of exosomes in cancers $(4,5)$, and it has been demonstrated that exosomal miRNAs and proteins can act as tumor biomarkers for clinical diagnosis or prognosis and that exosomes shuttle between cells to exchange genetic material, which promotes tumor progression, metastasis and prognosis; regulates the immune response; and affects the sensitivity of tumor cells to chemotherapy drugs (6-8). Therefore, exosomal miRNAs and proteins potentially play critical roles in cancers with high mortality rates.

\section{Exosome composition}

Exosomes are extracellular vesicles (EVs) that are produced and released by many different cells; and these vesicles range in size from 30 to $100 \mathrm{~nm}$ in diameter and contain a lipid bilayer $(9,10)$. Proteins, DNA, mRNAs, miRNAs and lipids are enriched in exosomes (11). Exosomes transfer nucleic acids and proteins between different cells, leading to both the transportation of materials and cell-cell communication $(6,12,13)$.

A set of distinct proteins are contained in exosomes (14), including heat-shock proteins (Hsp70, Hsp90), tetraspanins (CD9, CD81), ESCRT-related proteins (Alix, Tsg101), cytoskeletal proteins (actin, Tubulin) and GTPases (EEF1A1, 
EEF2) $(15,16)$. These proteins are known to be involved in biogenesis, the sorting and secretion of exosomes (17), antigen presentation, the organization of membrane microdomains, the cytoskeleton, and the endosomal system $(18,19)$. Typically, exosomes contain both cell-type specific proteins and proteins that are expressed in various cell types (20).

In addition to proteins, exosomes contain a significant amount of nucleic acids, including DNA, mRNAs, miRNAs, circular RNAs (circRNAs) and long noncoding RNAs (lncRNAs) (21). Of these, miRNAs are a class of well-known regulatory molecules that control posttranscriptional gene regulation (22). Increasing evidence has shown that exosomal miRNAs are associated with many diseases, such as cancers, diabetes and obesity (23-26). Interestingly, the miRNA content of exosomes is similar to that of the original tumor; thus, a series of studies has focused on exosomal miRNA profiles for cancer diagnostics (16). In particular, the shuttling of miRNAs may act as a tumor promoter or a tumor suppressor during tumorigenesis (27). Previous studies have uncovered exosomal miRNAs that are closely associated with tumorigenesis, metastasis and drug resistance in various kinds of cancers $(28,29)$. All of these findings suggest that exosomal miRNAs play a pivotal role in the diagnosis, treatment and prognosis of cancers $(30,31)$.

Additionally, cholesterols, diglycerides, phospholipids, glycerophospholipids, sphingomyelins and ceramides are enriched in exosomes (32). These lipids participate in exosome biogenesis, function and release. For example, the cellular trafficking of the tetraspanin CD82 to endosomes is regulated by the cholesterol content of the membrane, and ceramides can protect miRNAs from degradation by circulating RNases and govern the cellular distribution of the tetraspanin CD81. In addition, bioactive lipids such as prostaglandins, leukotrienes, fatty acids and lipid-related enzymes such as phospholipases A2 have been detected in exosomes (33).

\section{Exosome isolation}

Exosomes secreted by various types of living cells have been detected in a diverse range of bodily fluids, including peripheral blood, saliva, cerebrospinal fluid, ascites fluid, amniotic fluid, urine, breast milk and semen (31,34) (Fig. 2). It is clear that the utility of exosomes goes beyond basic research and extends to clinical practice. For this reason, an efficient and accurate method for exosome isolation is crucial.

Here, we compare the common methods for exosome isolation (Table I), including ultracentrifugation (UC), ultrafiltration (UF), immunomagnetic beads, size exclusion chromatography (SEC) and ExoQuick ${ }^{\mathrm{TM}}(35,36)$. UC is a common and simple method (37); however, recent studies indicated that more contaminants were found in exosomes isolated by UC compared to other methods mainly due to the presence of albumins. Furthermore, the high-velocity ultracentrifugation process could cause some exosomes to rupture, resulting in exosome loss (38). Recently, the challenges of UC approach have been again discussed, the conventional biophysical UC cannot distinguish exosomes from lipoproteins and oncosomes, other types of small EVs with sedimentation velocities and gradient densities similar to those of exosomes (39). UF does not require special equipment, although it leads to a reduction in the membranes' lifespan and a low isolation efficiency $(35,40)$. The use of immunomagnetic beads is an alternative method with high specificity and purity, but it is limited to exosomes with a known antigen and has a high reagent cost (35). Although SEC does not lead to significant albumin contamination, the efficiency is low $(35,37,41)$. ExoQuick ${ }^{\mathrm{TM}}$ produces excellent reproducibility and sensitivity. However, the proprietary reagents exhibit contamination from unknown sources, and the polymer leads to protein aggregation $(35,36,42,43)$. Moreover, the ExoQuick ${ }^{\mathrm{TM}}$ kit does not specifically precipitate exosomes, which means that other types of nanovesicles with similar sizes (30-100 nm) might also be coprecipitated (39). Recently, a new technique developed by the microfluidics community has been used to approach some of the problems with exosome isolation mentioned above. The most important feature of this method is exosome enrichment during isolation, which is beneficial for the detection of early-stage cancers. This microfluidics approach showed a superior recovery of 60-80\% compared to the conventional techniques of UC (6\%) and ExoQuick ${ }^{\mathrm{TM}}$ $(30 \%)$ based on nanoparticle tracking analysis (NTA) (43).

Indeed, the high quantity and purity of exosomes are extremely important for exosomal biology studies. Thus, western blotting should be used to determine whether exosomal protein markers (Alix, Tsg101, Hsp70 or others) are present in exosome isolations (44). Simultaneously, transmission electron microscopy (TEM) is often utilized to observe exosome morphology, NTA is used to measure particle size, and the bicinchoninic acid assay (BCA) is performed to examine the protein concentration of exosomes (45). Additionally, to ensure the sensitivity of isolations and achieve a robust result, pre-analytical factors should be taken into consideration (Table II) $(46,47)$.

\section{Exosomal miRNAs and proteins in lung cancer}

The latest report showed that lung cancer caused approximately 597,000 deaths in China in 2013 (3). Of lung cancer cases, approximately $95 \%$ are non-small-cell lung cancer (NSCLC) and small-cell lung cancer (SCLC) (48), which together represent the most common cause of cancer-related death globally $(49,50)$.

Serving as biomarkers. Exosomes and exosomal miRNAs differed between patients with lung cancer and controls (51). By comparing 12 specific tumor- and exosome-derived miRNAs (miR-17-3p, miR-21, miR-106a, miR-146, miR-155, miR-191, miR-192, miR-203, miR-205, miR-210, miR-212, and miR-214) in lung cancer, previous studies revealed that there was no significant difference between circulating miRNAs and tumor miRNAs, demonstrating that exosome-derived miRNAs can serve as diagnostic biomarkers for lung cancer (51). In a nude mouse model of subcutaneous primary and recurrent lung cancer xenografts in vivo, miR-21 and miR-155 were found to be up-regulated in serum exosomes derived from recurrent tumor-bearing nude mice compared to nontumor- or primary tumor-bearing nude mice (52), suggesting that these two miRNAs might be potential prognostic biomarkers for noninvasive diagnosis of recurrent lung cancer. In addition, Liu et al (53) first reported that elevation of plasma exosomal miR-23b-3p, miR-10b-5p and miR-21-5p predicted a significantly poor 

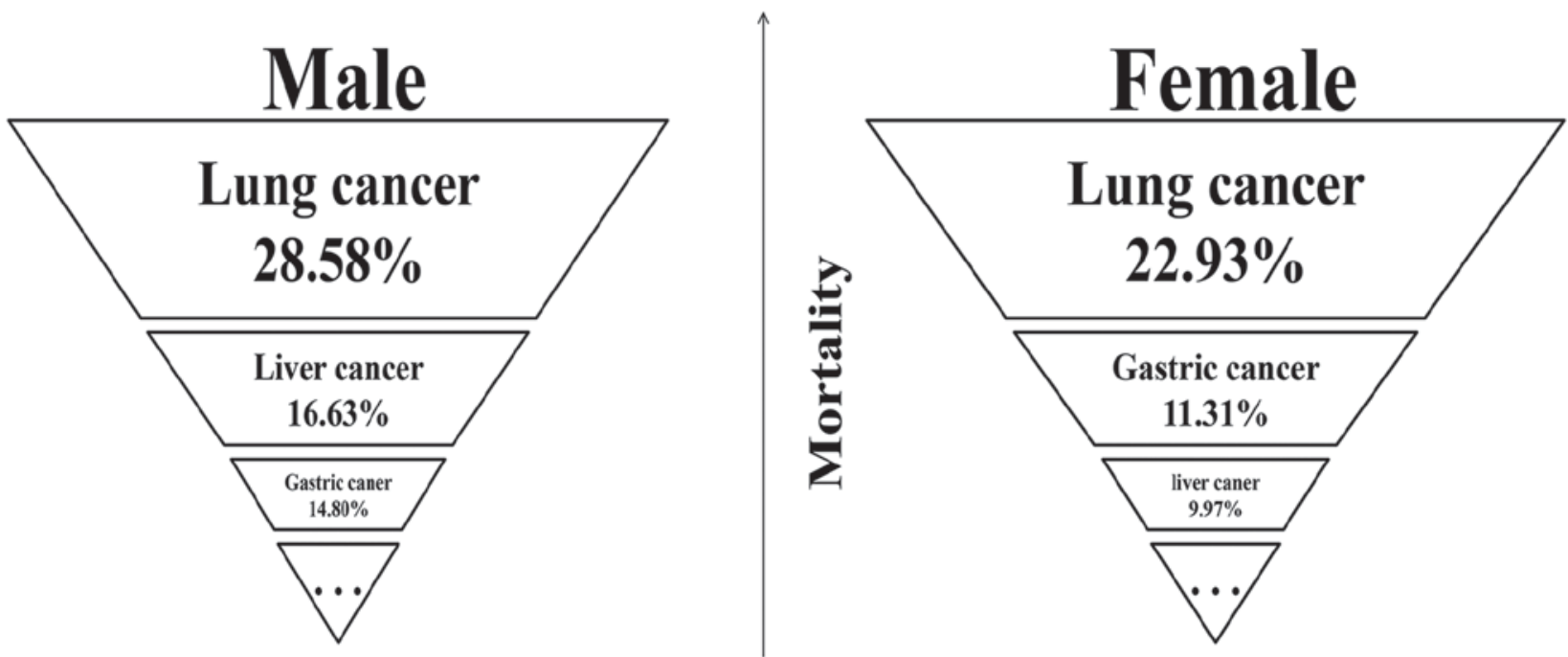

Figure 1. Top three mortality cancers in China, 2013. Liver cancer and gastric cancer are the top three leading causes of mortality in males. Lung cancer, gastric cancer and liver cancer are ranked the top three causes of mortality in females.

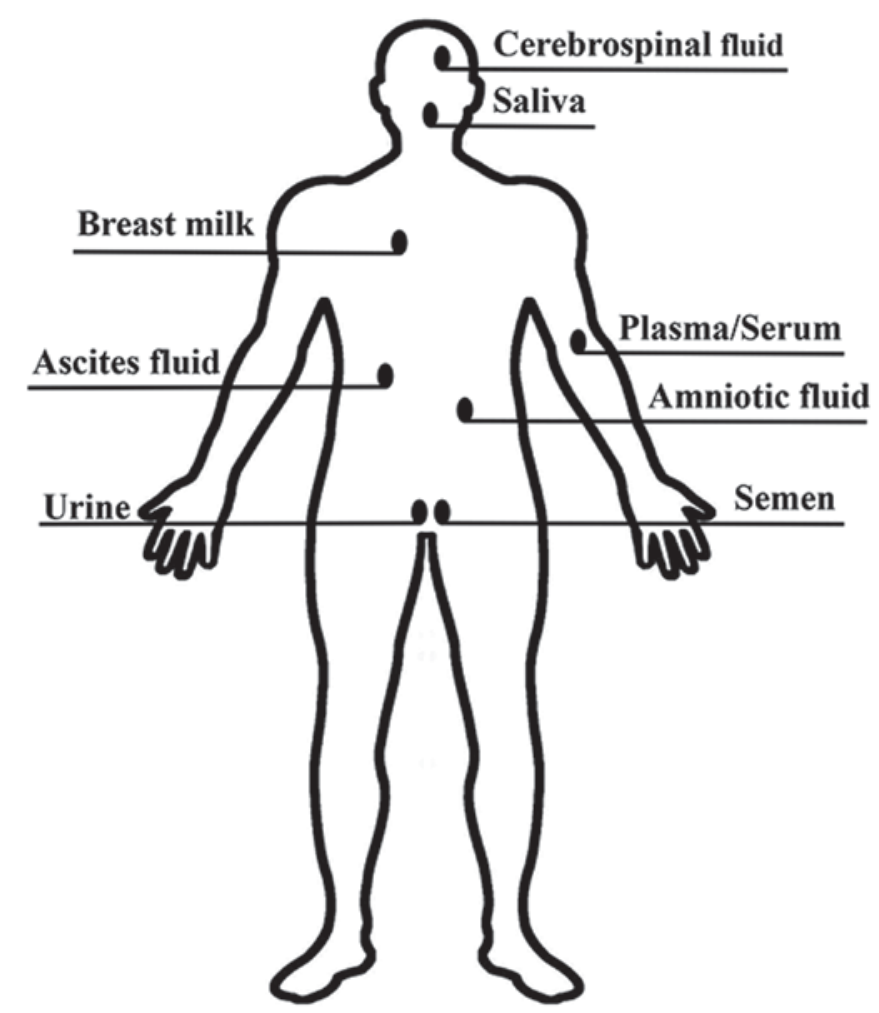

Figure 2. Exosomes exist in various bodily fluids. Exosomes can be detected in peripheral blood, saliva, cerebrospinal fluid, ascites fluid, amniotic fluid, urine, breast milk, semen and other bodily fluids.

survival, implying that these three exosomal miRNAs could serve as independent prognostic biomarkers for NSCLC.

Exosomal membrane-bound proteins, for example, the epidermal growth factor receptor (EGFR), NY-ESO-1 and CD91, are also promising diagnostic or prognostic biomarker candidates for lung cancer. Yamashita et al (54) demonstrated that the measurement of plasma exosomal proteins might be helpful for in vitro diagnosis, and exosomal EGFR was a potential diagnostic biomarker for the characterization of lung cancer. In NSCLC patients, exosomal NY-ESO-1 was a strong prognostic biomarker of poorer survival (55). CD91 expression was significantly increased in serum exosomes derived from patients with lung adenocarcinoma (ADC), and its detection power for early-stage patients was higher than that of carcinoembryonic antigen (CEA) (56).

Stimulating angiogenesis and inducing metastasis. Angiogenesis is essential for tumor growth, progression and metastasis (57). Liu et al (58) found that exosomal miR-21 derived from cigarette smoke extract (CSE)-transformed human bronchial epithelial (HBE) cells was elevated, and this increased exosomal miR-21 led to STAT3 activation and altered the vascular endothelial growth factor (VEGF) expression of recipient cells, promoting CSE-induced angiogenesis and the malignant transformation of HBE cells. These results provided a novel intervention strategy to prevent carcinogenesis of lung cancer. In addition, hypoxic lung cancer cell (hypoxic CL1-5)-derived exosomal miR-23a enhanced neovascularization and tumor growth, and serum exosomal miR-23a was also elevated in patients with lung cancer. These findings provided strong evidence that an increase in exosomal miR-23a contributes to angiogenesis, intravasation and extravasation in lung cancer (59).

Exosomes play a fundamental role in the premetastatic niche and metastasis (4). Results from Fabbri et al (60) indicated that miRNAs (miR-21/29a) derived from lung cancer cell line (A549 and SK-MES) exosomes activate members of the Toll-like receptor (TLR) family (murine TLR7 and human TLR8) in immune cells, leading to a TLR-mediated prometastatic inflammatory response that might ultimately trigger tumor growth and metastasis.

Mediating cisplatin (DDP) resistance. Lung cancer cell-derived exosomes could confer DDP resistance to other cancer cells. Qin et al (61) established A549 cells that were resistant to DDP (A549/DDP). Compared with A549 exosomes, miR-100-5p was downregulated by $75 \%$ in A549/DDP cell exosomes. Lower expression of miR-100-5p induced DDP resistance in recipient cells (other lung cancer cell lines). miR-100-5p negatively regulated $\mathrm{mTOR}$, the mammalian target of 
Table I. Comparison of exosome isolation methods.

\begin{tabular}{|c|c|c|c|c|c|}
\hline Author, year & Method & Principle & Advantages & Disadvantages & (Refs.) \\
\hline $\begin{array}{l}\text { Baranyai et al, } \\
\text { 2015; Peterson } \\
\text { et al, } 2015\end{array}$ & UC & $\begin{array}{l}\text { Separating the exosomes } \\
\text { through differential mass, } \\
\text { density and shape }\end{array}$ & $\begin{array}{l}\text { - Available technology } \\
\text { - Simple operation }\end{array}$ & $\begin{array}{l}\text { - The high velocity } \\
\text { ultracentrifugation } \\
\text { process could cause } \\
\text { some exosomes rupture } \\
\text { that results in some } \\
\text { exosomes loss } \\
\text { - Contaminated with } \\
\text { albumin and IgG } \\
\text { - Time consuming } \\
(16-20 \mathrm{~h})\end{array}$ & $(37,38)$ \\
\hline $\begin{array}{l}\text { Li et al, } 2017 \text {; } \\
\text { Zeringer et al, } \\
2015\end{array}$ & $\mathrm{UF}$ & $\begin{array}{l}\text { Depending on exosomal } \\
\text { size or molecular weight }\end{array}$ & $\begin{array}{l}\text { - No need of special } \\
\text { equipment } \\
\text { - Good portability }\end{array}$ & $\begin{array}{l}\text { Clogging and vesicle } \\
\text { trapping lead to reduce } \\
\text { the membranes' lifetime } \\
\text { and low isolation efficiency }\end{array}$ & $(35,40)$ \\
\hline Li et al, 2017 & $\begin{array}{l}\text { Immunom- } \\
\text { agnetic } \\
\text { beads }\end{array}$ & $\begin{array}{l}\text { Specific exosomal } \\
\text { antigens (receptors) } \\
\text { can be captured by } \\
\text { magnetic beads } \\
\text { (ligands) }\end{array}$ & $\begin{array}{l}\text { - High specificity and } \\
\text { purity } \\
\text { - No damage on the } \\
\text { integrity of the exosomes' } \\
\text { morphology and structure }\end{array}$ & $\begin{array}{l}\text { - High reagent cost } \\
\text { - Low yield }\end{array}$ & (35) \\
\hline $\begin{array}{l}\text { Li et al, 2017; } \\
\text { Baranyai et al, } \\
\text { 2015; Taylor } \\
\text { and Shah, } \\
2015\end{array}$ & SEC & $\begin{array}{l}\text { A porous stationary } \\
\text { phase is utilized to sort } \\
\text { exosomes out according } \\
\text { to the size }\end{array}$ & $\begin{array}{l}\text { - Obtaining high-purity } \\
\text { exosomes without } \\
\text { significant albumin } \\
\text { contamination } \\
\text { - Excellent } \\
\text { reproducibility } \\
\text { and sensitivity }\end{array}$ & $\begin{array}{l}\text { - Require dedicated } \\
\text { equipment } \\
\text { - Low efficiency }\end{array}$ & $(35,37,41)$ \\
\hline $\begin{array}{l}\text { Li } \text { et al, } 2017 ; \\
\text { Caradec et al, } \\
2014 ; \text { Ban } \\
\text { et al, } 2015\end{array}$ & ExoQuick $^{\mathrm{TM}}$ & $\begin{array}{l}\text { By the precipitation } \\
\text { approach }\end{array}$ & $\begin{array}{l}\text { - Efficient (around } \\
100 \% \text { ) and } \\
\text { reproducible } \\
\text { - Decreasing albumin } \\
\text { contamination } \\
\text { - Fast (within } 30 \mathrm{~min} \text { ) }\end{array}$ & $\begin{array}{l}\text { - Isolation procedure } \\
\text { should be under } \\
\text { acidic conditions }(\mathrm{pH}=4) \\
\text { Polymer precipitates } \\
\text { protein aggregation }\end{array}$ & $(35,36,42)$ \\
\hline
\end{tabular}

UC, ultracentrifugation; UF, ultrafiltration; SEC, size exclusion chromatography.

rapamycin, to alter the recipient lung cancer cells' resistance to DDP. Additionally, the chemosensitivity of NSCLC to DDP could be regulated by serum exosomal miR-146a-5p. The overexpression of miR-146a-5p reversed the resistance of A549/DDP cells by targeting Atg12 to inhibit autophagy (62). Furthermore, in a human bronchial epithelial cell (HBEC) model, exosomes derived from chemoresistant mesenchymal NSCLC cells were able to transfer chemoresistance and mesenchymal phenotypes to recipient cells, thereby enhancing resistance to gemcitabine and cisplatin/gemcitabine combination therapy (63).

\section{Exosomal miRNAs and proteins in liver cancer}

Liver cancer is a common malignancy with a high mortality rate both in China and around the world $(64,65)$. Liver cancer includes primary liver cancer (PLC) and secondary liver cancer. Hepatocellular carcinoma (HCC) and intrahepatic cholangiocarcinoma (ICC) are two different histologic types of PLC, which is the second most common cause of cancer-related deaths worldwide (66).

Serving as biomarkers. Differential expression of exosomal miRNAs in serum could serve as a diagnostic biomarker for HCC. Sohn et al (67) reported that the levels of serum exosomal miR-18a, miR-221, miR-222 and miR-224 were remarkably higher in HCC patients compared with patients with liver cirrhosis (LC) or chronic hepatitis B (CHB); however, the levels of serum exosomal miR-101, miR-106b, miR-122 and miR-195 were lower in HCC patients than in $\mathrm{CHB}$ patients. In addition, other studies have shown that expression of exosomal miR-21 and miR-125b was upregulated in HCC patients compared with $\mathrm{CHB}$ patients or healthy controls. More importantly, the levels of miR-21 
Table II. Pre-analytical considerations.

Author, year

Muller et al, 2014;

Witwer et al, 2013

Witwer et al, 2013

Witwer et al, 2013

Witwer et al, 2013

Muller et al, 2014
Venous blood from patients or healthy volunteers is collected into tubes without heparin-based anticoagulants, EDTA may be more appropriate.

Blood should be processed quickly at room temperature.

Collected blood should be handled gently and tubes should be vertically positioned prior to centrifugation.

Both plasma and serum can be used, but most studies indicate the isolation of exosomes prefers to plasma.

Harvested plasma or serum should be immediately used or stored at $-80^{\circ} \mathrm{C}$. and $\mathrm{miR}-125 \mathrm{~b}$ were higher in exosomes than in serum samples $(68,69)$.

Promoting proliferation, invasion and metastasis. Exosomal miRNAs could affect cellular gene expression and cellular behaviors in target cells (70). Wei et al (71) showed that exosomes derived from HCC cells (SMMC-7721, Hep3B, and Huh-7) could functionally deliver miRNAs to target cells and that $\mathrm{Vps} 4 \mathrm{~A}$ regulated the secretion and uptake of these miRNAs in hepatoma cells by utilizing exosomes as mediators. Vps4A-associated miRNAs are believed to regulate the PI3K/AKT signaling pathway and promote the proliferation, invasion and metastasis of HCC cells. It has been suggested that a large number of protumorigenic RNAs and proteins, such as the MET proto-oncogene, caveolins (CAV1, CAV2) and an S100 family member (S100A4), are enriched in metastatic HCC-derived exosomes (72-74). Moreover, He et al (75) showed that uptake of these shuttling molecules in exosomes derived from motile HCC cell lines (HKCI-C3, HKCI-8 and MHCC97 L) markedly enhanced the invasive and migratory abilities of nonmotile immortalized hepatocyte (MIHA) cell lines by activating the PI3K/AKT and MAPK signaling pathways and increasing the secretion of matrix metalloproteinases (MMP)-2 and MMP-9, which induced cell invasion.

Mediating sensitivity to sorafenib. Sorafenib is predominantly used for the treatment of liver cancer and can improve the overall survival of patients with advanced HCC (76). Exosomes may mediate sorafenib resistance in HCC cells. Guo et al (77) revealed that miR-122 contained in adipose tissue mesenchymal stem cell (AMSC) exosomes enhanced HCC cell sensitivity to chemotherapeutic agents. Compared with the control groups, the inhibitory effect of 5-fluorouracil (5-FU) or sorafenib on HCC cells (HepG2 and Huh7) treated with AMSC-derived exosomes (122-Exo) was significantly enhanced, thereby providing a new strategy for HCC therapy. An important mechanism of sorafenib resistance is the overexpression of c-Met, a proto-oncogene that serves as a receptor for hepatocyte growth factor (HGF) in tumor cells (78). Further investigations confirmed that HGF upregulation and c-Met/AKT pathway activation triggered sorafenib resistance induced by exosomes derived from HCC cells (MHCC-97L and $\mathrm{MHCC}-97 \mathrm{H})$, indicating that $\mathrm{HGF} / \mathrm{c}-$ Met might be a possible target for decreasing sorafenib resistance of $\mathrm{HCC}$ cells (79).

\section{Exosomal miRNAs and proteins in gastric cancer}

Gastric cancer (GC), a malignant tumor of the digestive system, is the second leading cause of cancer-related death and the fourth most common cancer worldwide (80). Although its incidence and mortality have appreciably decreased globally over recent decades, the mortality of GC is still relatively high in Asia (81).

Serving as biomarkers. Recent research suggested that serum exosomal miR-19b-3p and miR-106a-5 could be potential biomarkers for the early diagnosis of GC (82). Additionally, Tokuhisa et al (83) assessed exosomal miRNA profiles in peritoneal fluid and found that miR-21 and miR-1225-5p might be prognostic biomarkers for peritoneal recurrence after curative GC resection. miR-10b-5p, miR-195-5p, miR-20a-3p and miR-296-5p were significantly upregulated in serum exosomes derived from patients with GC and were able to discriminate GC patients from healthy controls (84).

Promoting metastasis. miR-214, miR-221 and miR-222 are commonly upregulated in gastric cancer tissue-derived mesenchymal stem cells (GC-MSCs) and tumor tissues; moreover, GC-MSC-derived exosomes deliver miR-221 to HGC-27 cells and promote the proliferation and migration (85). The serum exosomes of GC patients transport EGFR to liver cells, and EGFR activates HGF by suppressing $\mathrm{miR}-26 \mathrm{a} / \mathrm{b}$, stimulating the development of a liver-like microenvironment that promotes gastric cancer liver metastasis (86). In later studies, proliferation and Matrigel invasion of gastric cancer cells in the presence of exosomes derived from gastric cancer cells (SGC-7901) with either high (SGC/wt) or low (SGC/kd) CD97 expression were investigated, and the results indicated that CD97 promoted gastric cancer cell proliferation and invasion through exosome-mediated activation of the MAPK signaling pathway $(87,88)$.

Regulating the immune response. Compared with exosomes derived from the untreated malignant ascites of GC patients, exosomes derived from heat-treated malignant ascites 
Table III. Exosomal miRNAs in the top three mortality cancer types.

A, Lung cancer

\begin{tabular}{|c|c|c|c|c|c|c|c|}
\hline Author, year & miRNAs & Study design & Sample & Clinical significance & Approach & Performance & (Refs.) \\
\hline $\begin{array}{l}\text { Rabinowits } \\
\text { et al, } 2009\end{array}$ & $\begin{array}{l}\mathrm{miR}-17-\mathrm{p} / 21 / 106 \mathrm{a} / \\
146 / 155 / 191 / 192 / \\
203 / 205 / 210 / 212 / 214\end{array}$ & Case-control & Human plasma & $\begin{array}{l}\text { Diagnostic biomarkers } \\
\text { for NSCLC }\end{array}$ & Microarray & Increase & $(51)$ \\
\hline $\begin{array}{l}\text { Munagala } \\
\text { et al, } 2016\end{array}$ & miR-21/155 & $\begin{array}{l}\text { Animal } \\
\text { model } \\
\text { Cell model }\end{array}$ & $\begin{array}{l}\text { Athymic nude } \\
\text { mice } \mathrm{H} 1299 \text {, } \\
\text { Beas- } 2 \mathrm{~b}\end{array}$ & $\begin{array}{l}\text { Possible prognostic } \\
\text { markers for lung cancer } \\
\text { recurrence }\end{array}$ & $\begin{array}{l}\text { Microarray, } \\
\text { qPCR }\end{array}$ & Increase & $(52)$ \\
\hline $\begin{array}{l}\text { Liu et al, } \\
2017\end{array}$ & $\begin{array}{l}\operatorname{miR}-23 b-3 p / 10 b-5 p / \\
21-5 p\end{array}$ & Case-control & Human plasma & $\begin{array}{l}\text { Independent } \\
\text { non-invasive } \\
\text { prognostic markers for } \\
\text { NSCLC }\end{array}$ & qPCR & Increase & $(53)$ \\
\hline $\begin{array}{l}\text { Liu et al, } \\
2016\end{array}$ & miR-21 & $\begin{array}{l}\text { Patients } \\
\text { Cell model }\end{array}$ & $\begin{array}{l}\text { Human serum } \\
\text { CSE- } \\
\text { transformed } \\
\text { HBE cells }\end{array}$ & $\begin{array}{l}\text { Promoting } \\
\text { CSE-induced } \\
\text { angiogenesis and } \\
\text { malignant } \\
\text { transformation of HBE } \\
\text { cells }\end{array}$ & qPCR & Increase & $(58)$ \\
\hline $\begin{array}{l}\text { Hsu et al, } \\
2017\end{array}$ & miR-23a & $\begin{array}{l}\text { Patients } \\
\text { Cell model }\end{array}$ & $\begin{array}{l}\text { Human serum } \\
\text { Hypoxic CL1-5 }\end{array}$ & $\begin{array}{l}\text { Stimulating the } \\
\text { angiogenesis, intrava- } \\
\text { sation and extravasation } \\
\text { in lung cancer }\end{array}$ & qPCR & Increase & $(59)$ \\
\hline $\begin{array}{l}\text { Fabbri et al, } \\
2012\end{array}$ & $\operatorname{miR}-21 / 29 a$ & $\begin{array}{l}\text { Cell model, } \\
\text { Animal } \\
\text { model }\end{array}$ & $\begin{array}{l}\text { A549, SK-MES } \\
\text { WT B6 mice B6 } \\
\text { TLR7-/-mice }\end{array}$ & $\begin{array}{l}\text { Triggering tumour } \\
\text { growth and metastasis }\end{array}$ & qPCR & Increase & $(60)$ \\
\hline $\begin{array}{l}\text { Qin et al, } \\
2017\end{array}$ & miR-100-5p & Cell model & A549/DDP & $\begin{array}{l}\text { Altering the recipient } \\
\text { lung cancer cells' } \\
\text { resistance to DDP }\end{array}$ & $\begin{array}{l}\text { Microarray, } \\
\text { qPCR }\end{array}$ & Decrease & $(61)$ \\
\hline $\begin{array}{l}\text { Yuwen et al, } \\
2017\end{array}$ & $\operatorname{miR}-146 a-5 p$ & $\begin{array}{l}\text { Patients } \\
\text { Cell model }\end{array}$ & $\begin{array}{l}\text { Human serum } \\
\text { A549/DDP }\end{array}$ & $\begin{array}{l}\text { Reversing the resistance } \\
\text { of A549/DDP }\end{array}$ & qPCR & Increase & $(62)$ \\
\hline
\end{tabular}

B, Liver cancer

\begin{tabular}{|c|c|c|c|c|c|c|c|}
\hline Author, year & miRNAs & Study design & Sample & Clinical significance & Approach & Performance & (Refs.) \\
\hline $\begin{array}{l}\text { Sohn et al, } \\
2015\end{array}$ & $\begin{array}{l}\operatorname{miR}-18 \mathrm{a} / 221 / 222 / \\
224\end{array}$ & Case-control & Human serum & $\begin{array}{l}\text { Discriminating } \mathrm{HCC} \\
\text { from } \mathrm{LC} \text { or } \mathrm{CHB}\end{array}$ & qPCR & Increase & (67) \\
\hline $\begin{array}{l}\text { Sohn et al, } \\
2015\end{array}$ & $\begin{array}{l}\mathrm{miR}-101 / 106 \mathrm{~b} / 122 / \\
195\end{array}$ & Case-control & Human serum & $\begin{array}{l}\text { Discriminating } \\
\mathrm{HCC} \text { from } \mathrm{CHB}\end{array}$ & qPCR & Decrease & (67) \\
\hline $\begin{array}{l}\text { Wang et al, } \\
2014 ; \\
\text { Liu et al, } \\
2017\end{array}$ & miR-21/125b & Case-control & Human serum & $\begin{array}{l}\text { Discriminating } \mathrm{HCC} \\
\text { from } \mathrm{CHB} \text { or healthy } \\
\text { controls }\end{array}$ & qPCR & Increase & $(68,69)$ \\
\hline $\begin{array}{l}\text { Wei et al, } \\
2015\end{array}$ & $\begin{array}{l}\text { Vps4A-related } \\
\text { miRNAs }\end{array}$ & Cell model & $\begin{array}{l}\text { SMMC-7721, } \\
\text { Hep3B, Huh-7 }\end{array}$ & $\begin{array}{l}\text { Regulating PI3K/AKT } \\
\text { signaling pathway and } \\
\text { promoting proliferation, } \\
\text { invasion and metastasis } \\
\text { of HCC cells }\end{array}$ & $\begin{array}{l}\text { RNA } \\
\text { sequencing }\end{array}$ & Increase & (71) \\
\hline $\begin{array}{l}\text { Lou et al, } \\
2015\end{array}$ & miR-122 & Cell model & AMSC & $\begin{array}{l}\text { Enhancing the } \\
\text { effect } 5 \text {-FU or } \\
\text { sorafenib on HCC cells }\end{array}$ & qPCR & Increase & $(77)$ \\
\hline
\end{tabular}


Table III. Continued.

C, Gastric cancer

\begin{tabular}{|c|c|c|c|c|c|c|c|}
\hline Author, year & miRNAs & Study design & Sample & Clinical significance & Approach & Performance & (Refs.) \\
\hline $\begin{array}{l}\text { Wang et al, } \\
2017\end{array}$ & $\begin{array}{l}\operatorname{miR}-19 b-3 p / \\
106 a-5\end{array}$ & Case-control & $\begin{array}{l}\text { Human } \\
\text { serum }\end{array}$ & $\begin{array}{l}\text { Potential biomarkers } \\
\text { for the early diagnosis } \\
\text { of GC }\end{array}$ & qPCR & Increase & $(82)$ \\
\hline $\begin{array}{l}\text { Tokuhisa, } \\
\text { et al, } 2015\end{array}$ & $\begin{array}{l}\operatorname{miR}-21 / \\
1225-5 p\end{array}$ & $\begin{array}{l}\text { Patients } \\
\text { Cell model }\end{array}$ & $\begin{array}{l}\text { Peritoneum } \\
\text { lavage fluid, } \\
\text { OCUM-2M } \\
\text { OCUM-2MD3 }\end{array}$ & $\begin{array}{l}\text { Prognostic biomarkers } \\
\text { for peritoneal } \\
\text { recurrence after } \\
\text { curative GC } \\
\text { resection }\end{array}$ & $\begin{array}{l}\text { Microarray, } \\
\text { qPCR }\end{array}$ & Increase & $(83)$ \\
\hline $\begin{array}{l}\text { Huang et al, } \\
2017\end{array}$ & $\begin{array}{l}\text { miR-10b-5p/ } \\
\text { miR-195-5p/ } \\
\text { miR-20a-3p/ } \\
\text { miR-296-5p }\end{array}$ & Case-control & Human serum & $\begin{array}{l}\text { Discriminating GC } \\
\text { patients from healthy } \\
\text { controls }\end{array}$ & qPCR & Increase & $(84)$ \\
\hline $\begin{array}{l}\text { Wang et al, } \\
2014\end{array}$ & $\operatorname{miR}-221$ & $\begin{array}{l}\text { Patients } \\
\text { Cell model } \\
\text { Animal model }\end{array}$ & $\begin{array}{l}\text { Human tissue } \\
\text { GC-MSCs } \\
\text { BALB/cnu/nu } \\
\text { nude mice }\end{array}$ & $\begin{array}{l}\text { Promoting HGC-27 } \\
\text { cells proliferation } \\
\text { and migration }\end{array}$ & $\begin{array}{l}\text { Microarray, } \\
\text { qPCR }\end{array}$ & Increase & $(85)$ \\
\hline $\begin{array}{l}\text { Zheng et al, } \\
2017\end{array}$ & miR-21 & $\begin{array}{l}\text { Cell model } \\
\text { Animal model }\end{array}$ & $\begin{array}{l}\text { M2 macrophages } \\
\text { athymic } \\
\text { C57-nudemice }\end{array}$ & $\begin{array}{l}\text { Conferring DDP } \\
\text { resistance in GC } \\
\text { cells }\end{array}$ & $\begin{array}{l}\text { Microarray, } \\
\text { qPCR }\end{array}$ & Increase & $(92)$ \\
\hline $\begin{array}{l}\text { Wang et al, } \\
2018\end{array}$ & Anti-miR-214 & $\begin{array}{l}\text { Cell model } \\
\text { Animal model }\end{array}$ & $\begin{array}{l}\text { SGC7901, } \\
\text { SGC7901/ } \\
\text { DDP BALB/ } \\
\text { c-nude mice }\end{array}$ & $\begin{array}{l}\text { Reversing the resistance } \\
\text { of GC cells to DDP }\end{array}$ & qPCR & Increase & (93) \\
\hline
\end{tabular}

NSCLC, non-small-cell lung cancer; CSE-transformed HBE cells, cigarette smoke extrac-transformed human bronchial epithelial cells. Hypoxic lung cancer cell, hypoxic CL1-5; DDP, cisplatin; HCC, hepatocellular carcinoma; LC, liver cirrhosis; CHB, chronic hepatitis B; AMSC, adipose tissue mesenchymal stem cell; 5-FU, 5-fluorouracil; GC, gastric cancer; GC-MSCs, gastric cancer tissue-derived mesenchymal stem cells; qPCR, quantitative polymerase chain reaction.

contained higher concentrations of the heat shock proteins Hsp70 and Hsp60, which might play an important role in inducing a tumor-specific cytotoxic T lymphocyte (CTL) response in vitro and are involved in the promotion of dendritic cell (DC) maturation (89). Additionally, HSPs have been identified as damage-associated molecular patterns (DAMPs), a class of self-danger signals released by stressed cells that elicited immune responses. Mechanistically, HSPs respond to the innate immune system both directly with inflammation and indirectly by recruiting reinforcements (90). However, there is some evidence showing that HSPs have a dampening effect on the immune system under physiological conditions, indicating that HSPs are actually DAMPERs, a class of molecules that reduces the activity of the innate immune system (91).

Mediating DDP resistance. The level of miR-21 in exosomes derived from tumor-associated macrophages (M2 macrophages) has been shown to be increased, and exosomal miR-21 can be directly transferred from tumor-associated macrophages to gastric cancer cells, conferring DDP resistance to gastric cancer cells by downregulating PTEN and activating signaling through the PI3K/AKT pathway (92). However, exosome-delivered anti-miR-214 was able to reverse the resistance of gastric cancer cells to DDP, leading to suppressed migration in vitro, inhibited tumor growth in vivo, and increased cellular apoptosis (93). Additionally, MSC-derived exosomes significantly induced gastric cancer cell resistance to 5-FU both in vivo and ex vivo by activating the calmodulin-dependent protein kinase (CaM-K)/Raf/MEK/ERK pathway (94).

\section{Conclusion and future studies}

Exosomes have established a role in cancer biology, immunology, drug sensitivity and clinical diagnosis. In particular, exosomal miRNAs and proteins play important roles in cancers with high mortality rates (lung cancer, liver cancer and gastric cancer) (Tables III and IV).

On one hand, existing data indicate that the packaging of miRNAs into exosomes is a selective process and that the levels of specific exosomal miRNAs and proteins are changed in exosomes upon tumorigenesis. For these reasons, exosomal miRNAs and proteins can be served as a class of 
Table IV. Exosomal proteins in the top three mortality cancer types.

A, Lung cancer

\begin{tabular}{|c|c|c|c|c|c|c|c|}
\hline Author, year & Protein & Study design & Sample & Clinical significance & Approach & Performance & (Refs.) \\
\hline $\begin{array}{l}\text { Yamashita } \\
\text { et al, } 2017\end{array}$ & EGFR & Case-control & Human plasma & $\begin{array}{l}\text { Potential diagnostic } \\
\text { biomarker for } \\
\text { characterization of } \\
\text { lung cancer }\end{array}$ & ELISA & Increase & (54) \\
\hline $\begin{array}{l}\text { Sandfeld- } \\
\text { Paulsen } \\
\text { et al, } 2016\end{array}$ & NY-ESO-1 & Case-control & Human plasma & $\begin{array}{l}\text { A strongly prognostic } \\
\text { markers for poor } \\
\text { survival of NSCLC }\end{array}$ & Microarray & Increase & $(55)$ \\
\hline $\begin{array}{l}\text { Ueda et al, } \\
2014\end{array}$ & CD91 & Case-control & Human serum & $\begin{array}{l}\text { Diagnostic markers } \\
\text { for ADC }\end{array}$ & $\begin{array}{l}\text { ELISA } \\
\text { Mass } \\
\text { spectrometry }\end{array}$ & Increase & (56) \\
\hline
\end{tabular}

B, Liver cancer

\begin{tabular}{|c|c|c|c|c|c|c|c|}
\hline Author, year & Protein & Study design & Sample & Clinical significance & Approach & Performance & (Refs.) \\
\hline $\begin{array}{l}\text { He et al, } \\
2015\end{array}$ & $\begin{array}{l}\text { CAV1/CAV2/ } \\
\text { S100A4 }\end{array}$ & Cell model & $\begin{array}{l}\text { HKCI-C3, } \\
\text { HKCI-8 } \\
\text { MHCC97L }\end{array}$ & $\begin{array}{l}\text { Enhancing the } \\
\text { invasive and } \\
\text { migratory abilities } \\
\text { of non-motile } \\
\text { MIHA cells }\end{array}$ & $\begin{array}{l}\text { Western } \\
\text { blot } \\
\text { Mass } \\
\text { spectrometry }\end{array}$ & Increase & (75) \\
\hline $\begin{array}{l}\text { Qu et al, } \\
2016\end{array}$ & HGF & $\begin{array}{l}\text { Cell model } \\
\text { Animal model }\end{array}$ & $\begin{array}{l}\text { MHCC-97L, } \\
\text { MHCC-97H } \\
\text { BALB/c nu/nu } \\
\text { mice }\end{array}$ & $\begin{array}{l}\text { Improving sorafenib } \\
\text { resistance of HCC } \\
\text { cells }\end{array}$ & $\begin{array}{l}\text { ELISA } \\
\text { Western } \\
\text { blot }\end{array}$ & Increase & (79) \\
\hline
\end{tabular}

C, Gastric cancer

\begin{tabular}{|c|c|c|c|c|c|c|c|}
\hline Author, year & Protein & Study design & Sample & Clinical significance & Approach & Performance & (Refs.) \\
\hline $\begin{array}{l}\text { Zhang et al, } \\
2017\end{array}$ & EGFR & $\begin{array}{l}\text { Patients } \\
\text { Animal model } \\
\text { Cell model }\end{array}$ & $\begin{array}{l}\text { Human serum/ } \\
\text { tissue } \\
\text { BALB/ c-nu } \\
\text { nude mice } \\
\text { SGC7901 }\end{array}$ & $\begin{array}{l}\text { Promoting GC liver } \\
\text { metastasis }\end{array}$ & $\begin{array}{l}\text { ELISA } \\
\text { Western } \\
\text { blot }\end{array}$ & Increase & $(86)$ \\
\hline $\begin{array}{l}\text { Li et al, } 2015 ; \\
\text { Liu et al, } 2016\end{array}$ & CD97 & Cell model & SGC-7901 & $\begin{array}{l}\text { Promoting GC } \\
\text { cells proliferation } \\
\text { and invasion }\end{array}$ & $\begin{array}{l}\text { Western } \\
\text { blot }\end{array}$ & Increase & $(87,88)$ \\
\hline $\begin{array}{l}\text { Zhong et al, } \\
2011\end{array}$ & $\begin{array}{l}\text { Hsp70, } \\
\text { Hsp60 }\end{array}$ & Patients & $\begin{array}{l}\text { Heat-treated } \\
\text { malignant } \\
\text { ascites }\end{array}$ & $\begin{array}{l}\text { Inducing a CTL } \\
\text { response in vitro } \\
\text { and involving in the } \\
\text { promotion of } \mathrm{DC} \\
\text { maturation }\end{array}$ & $\begin{array}{l}\text { Western } \\
\text { blot }\end{array}$ & Increase & (89) \\
\hline
\end{tabular}

NSCLC, non-small-cell lung cancer; ADC, lung adenocarcinoma; MIHA, motile immortalized hepatocyte; HCC, hepatocellular carcinoma; CTL, cytotoxic T lymphocyte; DC, dendritic cell.

novel biomarkers for clinical applications in high-mortality cancers. Moreover, the specificity, sensitivity and diagnostic value of exosomal miRNAs and proteins may be superior to that of traditional tumor markers. On the other hand, exosomal miRNAs and proteins are delivered between tumor cells to transmit information and modulate signaling pathways. Taken 


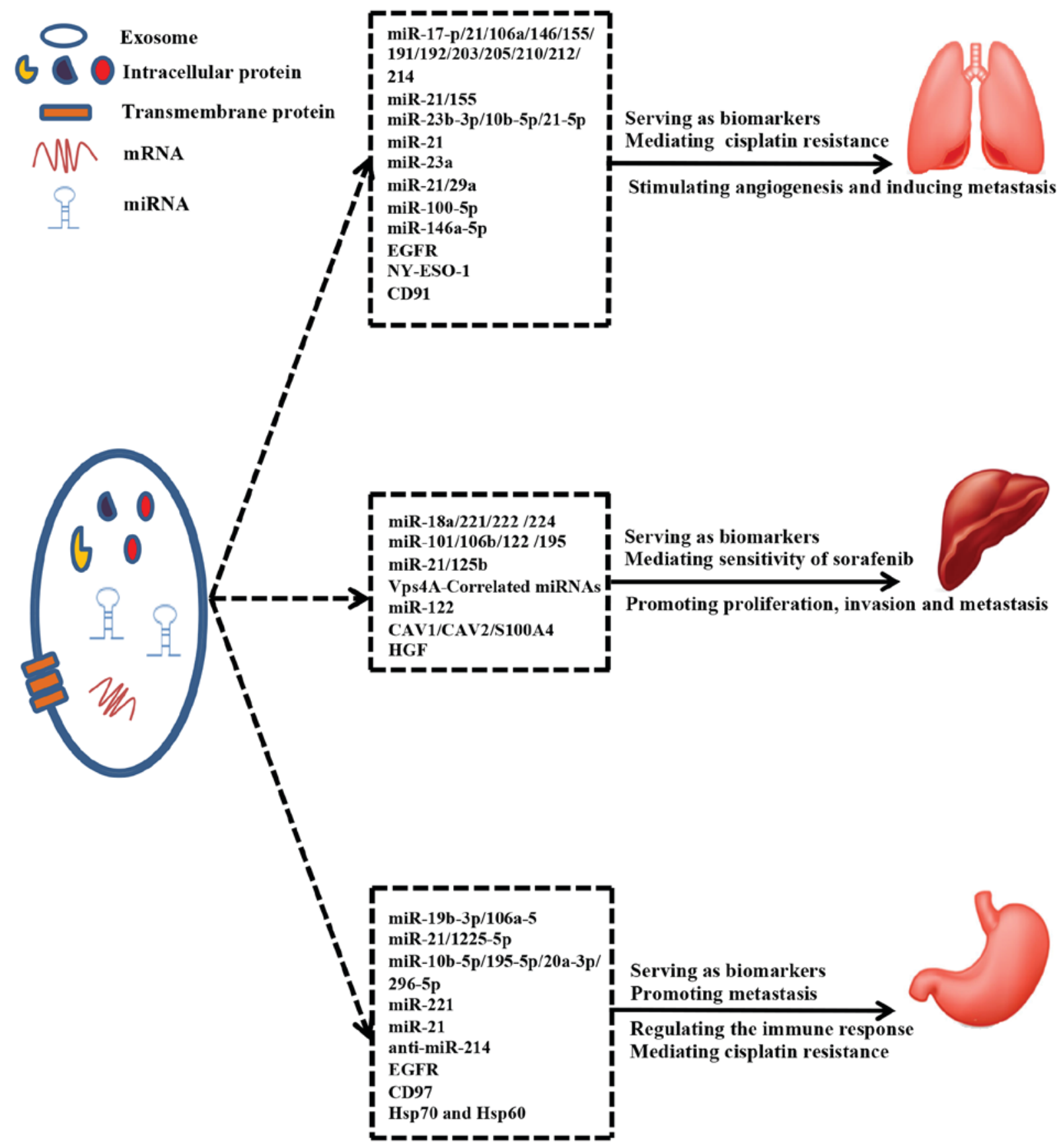

Figure 3. Exosomal miRNAs and proteins play vital roles in high-mortality cancers. Exosomal miRNAs and proteins can be used as diagnostic or prognostic biomarkers, promote tumor progression and metastasis, and simultaneously regulate immune response and tumor cells' sensitivity to chemotherapy drugs.

together, exosomal miRNAs and proteins perform the essential function of promoting tumor progression and metastasis as well as mediating the immune response and sensitivity of tumor cells to chemotherapy drugs (Fig. 3).

In the future, more robust techniques, such as RNA-Seq and mass spectrometry, can be used for the detection, characterization and discovery of exosomal miRNAs and proteins. Moreover, exosomes could efficiently deliver chemotherapeutic agents to cells and tissues. Therefore, these bioengineered, drug-loaded exosomes can serve as promising exosome mimetics for effective chemotherapeutic agent delivery, which will be applied for the target treatment of malignant tumors. Currently, the majority of research on chemotherapy resistance and exosomal microRNAs focuses on cisplatin, and little is known about other drugs. To identify more sensitive and specific exosomal miRNAs and proteins to guide personal chemotherapy selection, future studies should further elucidate the role and underlying mechanism of exosomal miRNAs and proteins in more diverse cancers with more chemotherapy drugs.

\section{Acknowledgements}

Not applicable.

\section{Funding}

This study was supported by the National Natural Science Foundation of China (grant no. 81772276) and the disciplines 
group construction project of Pudong Health Bureau of Shanghai (grant no. PWZxq2017-15).

\section{Availability of data and materials}

The datasets used or analyzed during the current study are available from the corresponding author on reasonable request.

\section{Authors' contributions}

LML was a major contributor in writing the manuscript. HL and XHL were responsible for the collection of the relevant literatures. HBH and SML revised the manuscript critically for important intellectual content. All authors read and approved the final manuscript.

\section{Ethics approval and consent to participate}

Not applicable.

\section{Patient consent for publication}

Not applicable.

\section{Competing interests}

The authors declare no competing interests.

\section{References}

1. Global Burden of Disease Cancer Collaboration, Fitzmaurice C, Allen C, Barber RM, Barregard L, Bhutta ZA, Brenner H Dicker DJ, Chimed-Orchir O, Dandona R, et al: Global, regional, and National cancer incidence, mortality, years of life lost, years lived with disability, and disability-adjusted life-years for 32 cancer groups, 1990 to 2015: A systematic analysis for the global burden of disease study. JAMA Oncol 3: 524-548, 2017.

2. Chen W, Zheng R, Zhang S, Zhao P, Zeng H and Zou X: Report of cancer incidence and mortality in China, 2010. Ann Transl Med 2: 61, 2014.

3. Zheng R, Zeng H, Zhang S and Chen W: Estimates of cancer incidence and mortality in China, 2013. Chin J Cancer 36: 66, 2017.

4. Zhou L, Lv T, Zhang Q, Zhu Q, Zhan P, Zhu S, Zhang J and Song Y: The biology, function and clinical implications of exosomes in lung cancer. Cancer Lett 407: 84-92, 2017.

5. Qi H, Liu C, Long L, Ren Y, Zhang S, Chang X, Qian X, Jia H, Zhao J, Sun J, et al: Blood exosomes endowed with magnetic and targeting properties for cancer therapy. ACS Nano 10: 3323-3333, 2016.

6. Greening DW, Gopal SK, Xu R, Simpson RJ and Chen W: Exosomes and their roles in immune regulation and cancer. Semin Cell Dev Biol 40: 72-81, 2015.

7. Taylor DD and Gercel-Taylor C: Exosomes/microvesicles: Mediators of cancer-associated immunosuppressive microenvironments. Semin Immunopathol 33: 441-454, 2011.

8. Zhao L, Liu W, Xiao J and Cao B: The role of exosomes and 'exosomal shuttle microRNA' in tumorigenesis and drug resistance. Cancer Lett 356: 339-346, 2015.

9. Kalluri R: The biology and function of exosomes in cancer. J Clin Invest 126: 1208-1215, 2016.

10. Frydrychowicz M, Kolecka-Bednarczyk A, Madejczyk M, Yasar S and Dworacki G: Exosomes-structure, biogenesis and biological role in non-small-cell lung cancer. Scand J Immunol 81: 2-10, 2015.

11. Aqil F, Munagala R, Jeyabalan J, Agrawal AK and Gupta R: Exosomes for the enhanced tissue bioavailability and efficacy of curcumin. AAPS J 19: 1691-1702, 2017.

12. Simons M and Raposo G: Exosomes-vesicular carriers for intercellular communication. Curr Opin Cell Biol 21: 575-581, 2009.
13. Schneider A and Simons M: Exosomes: Vesicular carriers for intercellular communication in neurodegenerative disorders. Cell Tissue Res 352: 33-47, 2013.

14. Mathivanan S, Ji H and Simpson RJ: Exosomes: Extracellular organelles important in intercellular communication. J Proteomics 73: 1907-1920, 2010.

15. Villarroya-Beltri C, Baixauli F, Gutiérrez-Vázquez C, Sánchez-Madrid F and Mittelbrunn M: Sorting it out: Regulation of exosome loading. Semin Cancer Biol 28: 3-13, 2014.

16. Hannafon BN and Ding WQ: Intercellular communication by exosome-derived microRNAs in cancer. Int J Mol Sci 14: 14240-14269, 2013.

17. Keerthikumar S, Chisanga D, Ariyaratne D, Al Saffar H, Anand S, Zhao K, Samuel M, Pathan M, Jois M, Chilamkurti N, et al: ExoCarta: A web-based compendium of exosomal cargo. J Mol Biol 428: 688-692, 2016.

18. Ludwig AK and Giebel B: Exosomes: Small vesicles participating in intercellular communication. Int J Biochem Cell Biol 44: 11-15, 2012.

19. Théry C, Zitvogel L and Amigorena S: Exosomes: Composition, biogenesis and function. Nat Rev Immunol 2: 569-579, 2002.

20. Iraci N, Leonardi T, Gessler F, Vega B and Pluchino S: Focus on extracellular vesicles: Physiological role and signalling properties of extracellular membrane vesicles. Int J Mol Sci 17: 171, 2016.

21. Li W, Li C, Zhou T, Liu X, Liu X, Li X and Chen D: Role of exosomal proteins in cancer diagnosis. Mol Cancer 16: 145, 2017.

22. Hannafon BN, Carpenter KJ, Berry WL, Janknecht R, Dooley WC and Ding WQ: Exosome-mediated microRNA signaling from breast cancer cells is altered by the anti-angiogenesis agent docosahexaenoic acid (DHA). Mol Cancer 14: 133, 2015.

23. Kapetanakis NI, Baloche V and Busson P: Tumor exosomal microRNAs thwarting anti-tumor immune responses in nasopharyngeal carcinomas. Ann Transl Med 5: 164, 2017.

24. Thomou T, Mori MA, Dreyfuss JM, Konishi M, Sakaguchi M, Wolfrum C, Rao TN, Winnay JN, Garcia-Martin R, Grinspoon SK, et al: Adipose-derived circulating miRNAs regulate gene expression in other tissues. Nature 542: 450-455, 2017.

25. Ying W, Riopel M, Bandyopadhyay G, Dong Y, Birmingham A, Seo JB, Ofrecio JM, Wollam J, Hernandez-Carretero A, $\mathrm{Fu} \mathrm{W}$, et al: Adipose tissue macrophage-derived exosomal miRNAs can modulate in vivo and in vitro insulin sensitivity. Cell 171: 372-384.e12, 2017.

26. Shi R, Zhao L, Cai W, Wei M, Zhou X, Yang G and Yuan L: Maternal exosomes in diabetes contribute to the cardiac development deficiency. Biochem Biophys Res Commun 483: 602-608, 2017.

27. Milane L, Singh A, Mattheolabakis G, Suresh M and Amiji MM: Exosome mediated communication within the tumor microenvironment. J Control Release 219: 278-294, 2015.

28. Ge Q, Zhou Y, Lu J, Bai Y, Xie X and Lu Z: miRNA in plasma exosome is stable under different storage conditions. Molecules 19: 1568-1575, 2014.

29. Pfeffer SR, Grossmann KF, Cassidy PB, Yang CH, Fan M, Kopelovich L, Leachman SA and Pfeffer LM: Detection of exosomal miRNAs in the plasma of melanoma patients. J Clin Med 4: 2012-2027, 2015.

30. Watahiki A, Macfarlane RJ, Gleave ME, Crea F, Wang Y, Helgason CD and Chi KN: Plasma miRNAs as biomarkers to identify patients with castration-resistant metastatic prostate cancer. Int J Mol Sci 14: 7757-7770, 2013.

31. Xu R, Greening DW, Rai A, Ji H and Simpson RJ: Highly-purified exosomes and shed microvesicles isolated from the human colon cancer cell line LIM1863 by sequential centrifugal ultrafiltration are biochemically and functionally distinct. Methods 87: 11-25, 2015.

32. Subra C, Laulagnier K, Perret B and Record M: Exosome lipidomics unravels lipid sorting at the level of multivesicular bodies. Biochimie 89: 205-212, 2007.

33. Record M, Carayon K, Poirot M and Silvente-Poirot S: Exosomes as new vesicular lipid transporters involved in cell-cell communication and various pathophysiologies. Biochim Biophys Acta 1841: 108-120, 2014

34. Raposo G and Stoorvogel W: Extracellular vesicles: Exosomes, microvesicles, and friends. J Cell Biol 200: 373-383, 2013.

35. Li P, Kaslan M, Lee SH, Yao J and Gao Z: Progress in exosome isolation techniques. Theranostics 7: 789-804, 2017.

36. Caradec J, Kharmate G, Hosseini-Beheshti E, Adomat H, Gleave $M$ and Guns E: Reproducibility and efficiency of serum-derived exosome extraction methods. Clin Biochem 47: 1286-1292, 2014 
37. Baranyai T, Herczeg K, Onódi Z, Voszka I, Módos K, Marton N, Nagy G, Mäger I, Wood MJ, El Andaloussi S, et al: Isolation of exosomes from blood plasma: Qualitative and quantitative comparison of ultracentrifugation and size exclusion chromatography methods. PLoS One 10: e0145686, 2015.

38. Peterson MF, Otoc N, Sethi JK, Gupta A and Antes TJ: Integrated systems for exosome investigation. Methods 87: 31-45, 2015.

39. Lu L and Risch HA: Exosomes: Potential for early detection in pancreatic cancer. Future Oncol 12: 1081-1090, 2016.

40. Zeringer E, Barta T, Li M and Vlassov AV: Strategies for isolation of exosomes. Cold Spring Harb Protoc 2015: 319-323, 2015.

41. Taylor DD and Shah S: Methods of isolating extracellular vesicles impact down-stream analyses of their cargoes. Methods 87: 3-10, 2015.

42. Ban JJ, Lee M, Im W and Kim M: Low pH increases the yield of exosome isolation. Biochem Biophys Res Commun 461: 76-79, 2015.

43. Marczak S, Richards K, Ramshani Z, Smith E, Senapati S, Hill R, Go DB and Chang HC: Simultaneous isolation and preconcentration of exosomes by ion concentration polarization. Electrophoresis: Feb 27, 2018 (Epub ahead of print).

44. Tauro BJ, Greening DW, Mathias RA, Ji H, Mathivanan S, Scott AM and Simpson RJ: Comparison of ultracentrifugation, density gradient separation, and immunoaffinity capture methods for isolating human colon cancer cell line LIM1863-derived exosomes. Methods 56: 293-304, 2012.

45. Vaswani K, Koh YQ, Almughlliq FB, Peiris HN and Mitchell MD: A method for the isolation and enrichment of purified bovine milk exosomes. Reprod Biol 17: 341-348, 2017.

46. Muller L, Hong CS, Stolz DB, Watkins SC and Whiteside TL: Isolation of biologically-active exosomes from human plasma. J Immunol Methods 411: 55-65, 2014.

47. Witwer KW, Buzás EI, Bemis LT, Bora A, Lässer C, Lötvall J, Nolte-'t Hoen EN, Piper MG, Sivaraman S, Skog J, et al: Standardization of sample collection, isolation and analysis methods in extracellular vesicle research. J Extracell Vesicles 2 , 2013.

48. Kadota T, Yoshioka Y, Fujita Y, Kuwano K and Ochiya T: Extracellular vesicles in lung cancer-From bench to bedside. Semin Cell Dev Biol 67: 39-47, 2017.

49. Nanavaty P, Alvarez MS and Alberts WM: Lung cancer screening: Advantages, controversies, and applications. Cancer Control 21: 9-14, 2014.

50. Pletnikoff PP, Laukkanen JA, Tuomainen TP, Kauhanen J, Rauramaa R, Ronkainen K and Kurl S: Cardiorespiratory fitness, C-reactive protein and lung cancer risk: A prospective population-based cohort study. Eur J Cancer 51: 1365-1370, 2015.

51. Rabinowits G, Gercel-Taylor C, Day JM, Taylor DD and Kloecker GH: Exosomal microRNA: A diagnostic marker for lung cancer. Clin Lung Cancer 10: 42-46, 2009.

52. Munagala R, Aqil $\mathrm{F}$ and Gupta RC: Exosomal miRNAs as biomarkers of recurrent lung cancer. Tumour Biol 37: 10703-10714, 2016.

53. Liu Q, Yu Z, Yuan S, Xie W, Li C, Hu Z, Xiang Y, Wu N, Wu L, Bai L and Li Y: Circulating exosomal microRNAs as prognostic biomarkers for non-small-cell lung cancer. Oncotarget 8 : 13048-13058, 2017.

54. Yamashita T, Kamada H, Kanasaki S, Maeda Y, Nagano K, Abe Y, Inoue M, Yoshioka Y, Tsutsumi Y, Katayama S, et al: Epidermal growth factor receptor localized to exosome membranes as a possible biomarker for lung cancer diagnosis Pharmazie 68: 969-973, 2013.

55. Sandfeld-Paulsen B, Aggerholm-Pedersen N, Bæk R, Jakobsen KR, Meldgaard P, Folkersen BH, Rasmussen TR, Varming K, Jørgensen MM and Sorensen BS: Exosomal proteins as prognostic biomarkers in non-small cell lung cancer. Mol Oncol 10: 1595-1602, 2016

56. Ueda K, Ishikawa N, Tatsuguchi A, Saichi N, Fujii R and Nakagawa H: Antibody-coupled monolithic silica microtips for highthroughput molecular profiling of circulating exosomes. Sci Rep 4: 6232, 2014

57. Ostrowski $\mathrm{K}$ and Kinsner A: Inhibition of angiogenesis in the treatment of tumors. Arch Immunol Ther Exp (Warsz) 49: 27-31, 2001.

58. Liu Y, Luo F, Wang B, Li H, Xu Y, Liu X, Shi L, Lu X, Xu W, $\mathrm{Lu} \mathrm{L}$, et al: STAT3-regulated exosomal miR-21 promotes angiogenesis and is involved in neoplastic processes of transformed human bronchial epithelial cells. Cancer Lett 370 : $125-135,2016$
59. Hsu YL, Hung JY, Chang WA, Lin YS, Pan YC, Tsai PH, Wu CY and Kuo PL: Hypoxic lung cancer-secreted exosomal miR-23a increased angiogenesis and vascular permeability by targeting prolyl hydroxylase and tight junction protein $\mathrm{ZO}-1$. Oncogene 36 : 4929-4942, 2017.

60. Fabbri M, Paone A, Calore F, Galli R, Gaudio E, Santhanam R, Lovat F, Fadda P, Mao C, Nuovo GJ, et al: MicroRNAs bind to Toll-like receptors to induce prometastatic inflammatory response. Proc Natl Acad Sci USA 109 E2110-E2116, 2012.

61. Qin X, Yu S, Zhou L, Shi M, Hu Y, Xu X, Shen B, Liu S, Yan D and Feng J: Cisplatin-resistant lung cancer cell-derived exosomes increase cisplatin resistance of recipient cells in exosomal miR-100-5p-dependent manner. Int J Nanomedicine 12: 3721-3733, 2017

62. Yuwen DL, Sheng BB, Liu J, Wenyu W and Shu YQ: MiR-146a-5p level in serum exosomes predicts therapeutic effect of cisplatin in non-small cell lung cancer. Eur Rev Med Pharmacol Sci 21: 2650-2658, 2017.

63. Lobb RJ, van Amerongen R, Wiegmans A, Ham S, Larsen JE and Möller A: Exosomes derived from mesenchymal non-small cell lung cancer cells promote chemoresistance. Int J Cancer 141: 614-620, 2017.

64. Wang FS, Fan JG, Zhang Z, Gao B and Wang HY: The global burden of liver disease: The major impact of China. Hepatology 60: 2099-2108, 2014

65. Li X and Xu WF: China's efforts to shed its title of 'Leader in liver disease'. Drug Discov Ther 1: 84-85, 2007.

66. Wong MC, Jiang JY, Goggins WB, Liang M, Fang Y, Fung FD, Leung $\mathrm{C}$, Wang $\mathrm{HH}$, Wong GL, Wong VW and Chan HL: International incidence and mortality trends of liver cancer: A global profile. Sci Rep 7: 45846, 2017.

67. Sohn W, Kim J, Kang SH, Yang SR, Cho JY, Cho HC, Shim SG and Paik YH: Serum exosomal microRNAs as novel biomarkers for hepatocellular carcinoma. Exp Mol Med 47: e184, 2015

68. Wang H, Hou L, Li A, Duan Y, Gao H and Song X: Expression of serum exosomal microRNA-21 in human hepatocellular carcinoma. Biomed Res Int 2014: 864894, 2014.

69. Liu W, Hu J, Zhou K, Chen F, Wang Z, Liao B, Dai Z, Cao Y, Fan $J$ and Zhou J: Serum exosomal miR-125b is a novel prognostic marker for hepatocellular carcinoma. Onco Targets Ther 10: 3843-3851, 2017.

70. Kogure T, Lin WL, Yan IK, Braconi C and Patel T: Intercellular nanovesicle-mediated microRNA transfer: A mechanism of environmental modulation of hepatocellular cancer cell growth. Hepatology 54: 1237-1248, 2011.

71. Wei JX,Lv LH, Wan YL, Cao Y,Li GL, Lin HM,Zhou R, Shang CZ $\mathrm{Cao} \mathrm{J}, \mathrm{He} \mathrm{H}$, et al: Vps4A functions as a tumor suppressor by regulating the secretion and uptake of exosomal microRNAs in human hepatoma cells. Hepatology 61: 1284-1294, 2015.

72. Mishra SK, Siddique HR and Saleem M: S100A4 calcium-binding protein is key player in tumor progression and metastasis: Preclinical and clinical evidence. Cancer Metastasis Rev 31: 163-172, 2012.

73. Tse EY, Ko FC, Tung EK, Chan LK, Lee TK, Ngan ES, Man K, Wong AS, Ng IO and Yam JW: Caveolin-1 overexpression is associated with hepatocellular carcinoma tumourigenesis and metastasis. J Pathol 226: 645-653, 2012.

74. Cokakli M, Erdal E, Nart D, Yilmaz F, Sagol O, Kilic M, Karademir S and Atabey N: Differential expression of Caveolin-1 in hepatocellular carcinoma: Correlation with differentiation state, motility and invasion. BMC Cancer 9: 65, 2009.

75. He M, Qin H, Poon TC, Sze SC, Ding X, Co NN, Ngai SM, Chan TF and Wong N: Hepatocellular carcinoma-derived exosomes promote motility of immortalized hepatocyte through transfer of oncogenic proteins and RNAs. Carcinogenesis 36: 1008-1018, 2015.

76. Cheng AL, Kang YK, Chen Z, Tsao CJ, Qin S, Kim JS, Luo R, Feng J, Ye S, Yang TS, et al: Efficacy and safety of sorafenib in patients in the Asia-Pacific region with advanced hepatocellular carcinoma: A phase III randomised, double-blind, placebo-controlled trial. Lancet Oncol 10: 25-34, 2009.

77. Lou G, Song X, Yang F, Wu S, Wang J, Chen Z and Liu Y: Exosomes derived from miR-122-modified adipose tissue-derived MSCs increase chemosensitivity of hepatocellular carcinoma. J Hematol Oncol 8: 122, 2015. 
78. You H, Ding W, Dang H, Jiang Y and Rountree CB: c-Met represents a potential therapeutic target for personalized treatment in hepatocellular carcinoma. Hepatology 54: 879-889, 2011.

79. Qu Z, Wu J, Wu J, Luo D, Jiang C and Ding Y: Exosomes derived from HCC cells induce sorafenib resistance in hepatocellular carcinoma both in vivo and in vitro. J Exp Clin Cancer Res 35: $159,2016$.

80. Ferro A, Peleteiro B, Malvezzi M, Bosetti C, Bertuccio P, Levi F, Negri E, La Vecchia C and Lunet N: Worldwide trends in gastric cancer mortality (1980-2011), with predictions to 2015, and incidence by subtype. Eur J Cancer 50: 1330-1344, 2014.

81. Peleteiro B, Severo M, La Vecchia C and Lunet N: Model-based patterns in stomach cancer mortality worldwide. Eur J Cancer Prev 23: 524-531, 2014

82. Wang N, Wang L, Yang Y, Gong L, Xiao B and Liu X: A serum exosomal microRNA panel as a potential biomarker test for gastric cancer. Biochem Biophys Res Commun 493: 1322-1328, 2017.

83. Tokuhisa M, Ichikawa Y, Kosaka N, Ochiya T, Yashiro M, Hirakawa K, Kosaka T, Makino H, Akiyama H, Kunisaki C and Endo I: Exosomal miRNAs from peritoneum lavage fluid as potential prognostic biomarkers of peritoneal metastasis in gastric cancer. PLoS One 10: e0130472, 2015.

84. Huang Z, Zhu D, Wu L, He M, Zhou X, Zhang L, Zhang H, Wang W, Zhu J, Cheng W, et al: Six serum-based miRNAs as potential diagnostic biomarkers for gastric cancer. Cancer Epidemiol Biomarkers Prev 26: 188-196, 2017.

85. Wang M, Zhao C, Shi H, Zhang B, Zhang L, Zhang X, Wang S, Wu X, Yang T, Huang F, et al: Deregulated microRNAs in gastric cancer tissue-derived mesenchymal stem cells: Novel biomarkers and a mechanism for gastric cancer. Br J Cancer 110: 1199-1210, 2014.

86. Zhang H, Deng T, Liu R, Bai M, Zhou L, Wang X, Li S, Wang X, Yang $\mathrm{H}$, Li J, et al: Exosome-delivered EGFR regulates liver microenvironment to promote gastric cancer liver metastasis. Nat Commun 8: 15016, 2017.
87. Li C, Liu DR, Li GG, Wang HH, Li XW, Zhang W, Wu YL and Chen L: CD97 promotes gastric cancer cell proliferation and invasion through exosome-mediated MAPK signaling pathway. World J Gastroenterol 21: 6215-6228, 2015.

88. Liu D, Li C, Trojanowicz B, Li X, Shi D, Zhan C, Wang Z and Chen L: CD97 promotion of gastric carcinoma lymphatic metastasis is exosome dependent. Gastric Cancer 19: 754-766, 2016.

89. Zhong H, Yang Y, Ma S, Xiu F, Cai Z, Zhao H and Du L: Induction of a tumour-specific CTL response by exosomes isolated from heat-treated malignant ascites of gastric cancer patients. Int J Hyperthermia 27: 604-611, 2011.

90. Broere F, van der Zee R and van Eden W: Heat shock proteins are no DAMPs, rather 'DAMPERs'. Nat Rev Immunol 11: 565, 2011.

91. van Eden W, Spiering R, Broere F and van der Zee R: A case of mistaken identity: HSPs are no DAMPs but DAMPERs. Cell Stress Chaperones 17: 281-292, 2012.

92. Zheng P, Chen L, Yuan X, Luo Q, Liu Y, Xie G, Ma Y and Shen L: Exosomal transfer of tumor-associated macrophage-derived miR-21 confers cisplatin resistance in gastric cancer cells. J Exp Clin Cancer Res 36: 53, 2017.

93. Wang X, Zhang H, Bai M, Ning T, Ge S, Deng T, Liu R, Zhang L, Ying $\mathrm{G}$ and $\mathrm{Ba} Y$ : Exosomes serve as nanoparticles to deliver anti-miR-214 to reverse chemoresistance to cisplatin in gastric cancer. Mol Ther 26: 774-783, 2018.

94. Ji R, Zhang B, Zhang X, Xue J, Yuan X, Yan Y, Wang M, Zhu W, Qian $\mathrm{H}$ and $\mathrm{Xu} \mathrm{W}$ : Exosomes derived from human mesenchymal stem cells confer drug resistance in gastric cancer. Cell Cycle 14: 2473-2483, 2015

This work is licensed under a Creative Commons Attribution-NonCommercial-NoDerivatives 4.0 International (CC BY-NC-ND 4.0) License. 